\title{
Sistem Pakar Diagnosa Gangguan Hiperaktif Pada Anak Dengan Metode Naive Bayes Berbasis Web
}

\author{
Yunia Ervinaeni, Aziz Setyawan Hidayat, Eri Riana
}

Program Studi Teknik Informatika, STMIK Nusa Mandiri, Jakarta, Indonesia

\begin{abstract}
Abstrak
Gangguan pemusatan perhatian atau lebih dikenal dengan istilah ADHD (Attention Deficit Hyperactivity Disorder) merupakan salah satu masalah psikiatri utama yang sering ditemukan pada anak. Gangguan hiperaktif biasanya terlihat pada anak-anak dan seiring bertambahnya usia semakin susah untuk ditangani. Terdapat 3 gangguan hiperaktif yang diambil dalam penelitian ini yaitu hiperaktif, Impulsif, Inattension (Masalah Kepribadian). Untuk membantu mendiagnosa gangguan hiperaktif tersebut, maka dibuat aplikasi sistem pakar diagnosa gangguan hiperaktif pada anak yang dapat memudahkan masyarakat dalam mendiagnosa gangguan hiperaktif pada anak. Pembuatan aplikasi sistem pakar berbasis web ini menggunakan metode Naive Bayes. Metode Naive Bayes merupakan suatu klasifikasi berpeluang sederhana berdasarkan aplikasi teorema Bayes dengan asumsi antar variable (independen) kehadiran atau ketiadaan dari suatu kejadian tertentu dari suatu kelompok tidak berhubungan dengan kehadiran atau ketiadaan dari kejadian lainnya. Hasil akhir yang diberikan berupa persentase angka diagnosa gangguan hiperaktif pada anak yang dialami.
\end{abstract}

Kata Kunci: Attention Deficit Hyperactivity Disorder (ADHD), Metode Naive Bayes, Sistem Pakar.

\begin{abstract}
Absract
Disorder concentration attention or better known as ADHD (Attention Deficit Hyperactivity Disorder) is one of the main psychiatric problems that are often found in children. Hyperactive disorders are usually seen in children and as we get older the more difficult to deal with. There were 3 hyperactive disorders taken in this study namely hyperactivity, Impulsivity, Inattetion (Personality Problems). To help diagnose these hyperactive disorders, an expert system application is made to diagnose hyperactive disorders in children that can facilitate the public in diagnosing hyperactive disorders in children. Making this web-based expert system application uses the Naive Bayes method. The Naive Bayes method is a simple opportunity classification based on the application of the Bayes theorem with the assumption that between variables (independent) the presence or absence of a particular event from a group is not related to the presence or absence of other events. The final results are given in the form of a percentage of the diagnosis of hyperactivity in children.
\end{abstract}

Keywords: Attention Deficit Hyperactivity Disorder (ADHD), the Naive Method Bayes, Expert System.

\section{PENDAhUluan}

Dalam kehidupan masyarakat disadari atau tidak disadari ada sebagian masyarakat yang mengalami gangguan perilaku tidak normal yang terjadi pada lingkungan masyarakat. Menurut Novriana (2014:141) mengatakan bahwa "Gangguan pemusatan perhatian dan hiperaktifitas (GPPH) atau dalam istilah kedokteran lebih dikenal dengan singkatan ADHD (Attention Deficit Hyperactivity Disorder) adalah salah satu masalah psikiatri utama yang sering ditemukan pada anak". ADHD merupakan salah satu gangguan perkembangan peningkatan aktifitas motorik yang terjadi pada anak yang menyebabkan aktifitas anak yang berlebihan atau diluar batas normal. Dalam perspektif pendidikan, jika ada seorang anak yang mengalami gangguan ADHD dapat mengalami gangguan belajar. Kemudian, dalam perspektif psikologi dan sosiologi, anak dengan gangguan ADHD dapat mengalami kesulitan berperilaku, kesulitan bersosial, dan kesulitan lain yang berkaitan.

Anak yang mengalami gangguan perilaku tidak normal ADHD biasanya disebut dengan gangguan autisme oleh masyarakat awam yang sebenarnya kedua pengertian tersebut berbeda. Anak yang mengalami gangguan perilaku tidak normal ADHD merupakan gangguan perilaku yang sifatnya hiperaktif dan cenderung memberikan respon yang berlebihan. Menurut Wijaya (2015:22) mengatakan bahwa "Autisme adalah gangguan perkembangan anak yang disebabkan oleh adanya gangguan pada sistem saraf pusat yang mengakibatkan gangguan dalam interaksi sosial, komunikasi dan perilaku". Masalah yang terjadi pada gangguan perilaku ADHD pada anak ini merupakan masalah yang perlu diperhatikan khusus karena perilaku tersebut dapat mengganggu dan menghambat anak dalam proses belajar dan akan mengakibatkan dampak yang buruk pada perkembangan kehidupan sosialnya.

Kurangnya informasi yang dimiliki orang tua anak yang mengidap ADHD merupakan salah satu faktor yang menyebabkan lambatnya penanganan dalam mengatasi gangguan ADHD. Untuk mempercepat penanganan tersebut dalam penyediaan informasi dapat dilakukan dengan memanfaatkan kecerdasan buatan yaitu sistem pakar berbasis web yang dapat memudahkan masyarakat dalam mendiagnosa gangguan hiperaktif pada anak. Adapun aplikasi ini terdiri dari suatu sistem yang mampu mentransfer kepakaran dari seorang pakar ke sebuah aplikasi berbasis web.

\section{TEORITIS}

\subsection{Sistem Pakar}


Menurut Fanny, dkk (2017:13) mengatakan bahwa "Sistem pakar adalah sistem yang berusaha mengadopsi pengetahuan manusia ke komputer yang dirancang untuk memodelkan kemampuan menyelesaikan masalah seperti layaknya seorang pakar". Dari pengertian tersebut penulis berpendapat bahwa sistem pakar yaitu suatu sistem yang di dalamnya berisi kecerdasan seorang pakar yang dipindahkan kedalam suatu sistem yang nantinya akan diolah oleh suatu program agar dapat digunakan dalam berbagai bidang, salah satunya antara lain bidang teknik, kedokteran dan otomotif. Program sistem pakar sangat membantu untuk mengambil keputusan karena penerapannya sangat luas.

Sistem pakar memungkinkan seseorang yang kurang memahami suatu permasalahan terbantu melalui aplikasi sistem pakar yang dibuat. Permasalahan yang telah diidentifikasi dapat diproses dan di olah sedemikian rupa sehingga dihasilkan suatu kesimpulan mengenai suatu permasalahan.

Tabel 1. Perbedaan pakar manusia dengan sistem pakar

\begin{tabular}{ll}
\hline \multicolumn{3}{c}{ Pakar Manusia } & \multicolumn{1}{c}{ Sistem Pakar } \\
\hline $\begin{array}{l}\text { Terbatas waktu karena manusia } \\
\text { membutuhkan istirahat }\end{array}$ & Tidak terbatas karena dapat digunakan kapanpun juga \\
Tempat akses bersifat lokal pada & Dapat digunakan di berbagai tempat \\
suatu tempat saja dimana pakar & \\
berada & \\
$\begin{array}{l}\text { Pengetahuan bersifat variable dan } \\
\text { dapat berubah-ubah tergantung }\end{array}$ & Pengetahuan bersifat konsisten \\
situasi & \\
$\begin{array}{l}\text { Kecepatan untuk menemukan solusi } \\
\text { sifatnya bervariasi }\end{array}$ & Kecepatan untuk memberikan solusi konsisten dan \\
Biaya yang harus dibayar untuk & Biaya yang dikeluarkan lebih murah \\
konsultasi biasanya sangat mahal & \\
\hline
\end{tabular}

Sumber: (Ma'rifati \& Kesuma, 2018)

\subsection{Gangguan Hiperaktif Pada Anak}

Menurut Setianingsih, dkk (2018:194) mengatakan bahwa "Hiperaktivitas (GPPH) di definisikan sebagai pola persisten dan usia perkembangan yang tidak tepat dari gangguan pemusatan perhatian, hiperaktif-impulsif, atau keduanya". Anak dengan kecenderungan hiperaktifitas akan selalu bergerak dan tidak pernah merasakan adanya kesenangan dari sebuah mainan atau permainan yang biasanya digemari oleh anak seusia mereka, hal ini dikarenakan perhatian mereka cepat beralih dari suatu fokus ke fokus yang lain.

Ditinjau dari sudut pandang psikologi, anak merupakan pribadi sosial. Apabila pada anak hiperaktif tersebut mendapat sambutan baik ataupun bimbingan kearah yang benar maka perkembangan pribadinya akan lebih terarah. Bila anak hiperaktif tersebut tidak mendapatkan sambutan baik atau bimbingan dari keluarga dan lingkungannya, maka anak akan menjadi rendah diri, bisa juga rasa egoisnya tinggi sekali dan bersifat mengabaikan keluarga dan lingkungannya, juga keadaan jiwanya sangat labil. Anak hiperaktif ini sangat memerlukan hubungan yang dekat melalui bimbingan yang baik dan benar, orang tua dan guru tidak seharusnya bersikap mengabaikan dan menyerah. Setiap prilaku anak yang tidak dapat diterima harus dicegah melalui bimbingan yang terarah. Orang tua dan guru harus memiliki kesabaran yang lebih untuk membimbing anak hiperaktif dan harus dilakukan secara berulang-ulang. Ada beberapa faktor yang menyebabkan anak menjadi hiperaktif antara lain :

1. Memanjakan Anak

Memanjakan anak dapat diartikan dengan memperlakukan anak terlalu manis serta mengalah pada anak. Anak yang sering dimanja sering memilih caranya sendiri agar terpenuhi kebutuhannya. Perilaku anak tersebut dikarenakan kurangnya disiplin yang diberikan oleh orang tua kepada anak tersebut. Apabila cara tersebut tetap dilakukan mengakibatkan anak lebih berlaku semaunya. Anak yang dimanja mengakibatkan pengarahan yang seharusnya diberikan kepadanya berkurang. Apabila berada disekolah, anak tersebut lebih memilih berjalan-jalan dan berdiri dari pada mendengarkan pelajaran yang diberikan oleh guru. Memanjakan anak dengan memenuhi semua keinginannya dan kebutuhannya itu harus dihindari. Orang tua harus bertahan dengan peraturan yang telah diberikan dan mendorong anak agar menaatinya, sikap bertahan ini bukan berarti kejam atau keras tetapi sebaliknya justru untuk membina dan mengajarkan pada anak tentang apa yang harus mereka lakukan. Anak yang manja biasanya akan sulit bergaul dengan teman seumurannya karena selalu ingin menang, tidak punya tanggung jawab, mengalami kesulitan di sekolah dan tidak mematuhi peraturan kelas, sering membantah, hanya berbuat menurut keinginannya. Jelaslah bahwa anakanak semacam ini akan menemui kesulitan dalam bergaul.

2. Kurang Disiplin dan Pengawasan

Anak yang kurang disiplin dan pengawasan akan berbuat sesuka hatinya, sebab prilakunya kurang dibatasi. Dan apa yang dilakukan oleh anak tersebut dibiarkan begitu saja tanpa ada perhatian dari orang tua. Jika anak 
dibiarkan begitu saja untuk berbuat sesuka hatinya dalam rumah tanpa adanya disiplin dan pengawasan, maka anak tersebut akan berbuat sesuka hatinya ditempat lain. Selain itu orang lain juga akan sulit untuk mengendalikannya di tempat lain baik itu disekolah.

3. Orientasi Kesenangan

Anak yang memiliki kepribadian yang berorientasi kesenangan umumnya akan memiliki ciri-ciri hiperaktif secara sosio-psikologis dan harus didik sedikit berbeda sehingga dapat mendengarkan dan menyesuaikan diri. Anak yang mempunyai orientasi kesenangan ingin memuaskan kebutuhan atau keinginan sendiri. Anak tersebut lebih memperhatikan kesenangan yang berasal dari perilakunya dari pada memikirkan hukumannya. Misalnya anak tersebut mungkin tahu bahwa apabila melanggar peraturan maka akan menerima hukuman. Namun apabila hal tersebut menyenangkannya, anak tersebut akan melakukan walaupun menerima hukumannya nanti. Anak hiperaktif akan melakukan apa yang menjadi kesenangannya dan tidak peduli dengan aturan yang sudah ada dan ditentukan oleh orang lain. Apabila menyuruh anak tersebut untuk melakukan tugas yang sesuai dengan keinginannya maka ia akan melakukannya. Sebaliknya apabila ingin menyuruhnya apa yang tidak disenangi olehnya maka anak itu tidak akan melakukannya. Anak hiperaktif melakukan sesuatu akan berfikir dahulu sebelum berbuat, namun hal seperti itu tidak selalu benar. Anak melakukan hal seperti itu karena keinginannya harus terjadi.

\subsection{Naive Bayes Classifier}

Naive Bayes Classifier merupakan suatu klasifikasi berpeluang sederhana berdasarkan aplikasi teorema Bayes dengan asumsi antar variable penjelas saling bebas (independen) yaitu kehadiran atau ketiadaan dari suatu kejadian tertentu dari suatu kelompok tidak berhubungan dengan kehadiran atau ketiadaan dari kejadian lainnya.

Secara umum, teorema Bayes dinyatakan sebagai:

$$
P(A \mid B)=\frac{P(B \mid A) \cdot P(A)}{P(B)}
$$

Dalam notasi ini $\mathrm{P}(\mathrm{A} \mid \mathrm{B})$ berarti peluang kejaian A bila $\mathrm{B}$ terjadi dan $\mathrm{P}(\mathrm{B} \mid \mathrm{A})$ peluang kejadian $\mathrm{B}$ bila $\mathrm{A}$ terjadi. Contoh Perhitungan Metode Naive Bayes Classifier untuk Mendeteksi Penyakit pencernaan. Penyakit saluran pencernaan adalah penyakit yang menyerang organ tubuh pada sistem pencernaan manusia. Berikut adalah data yang didapatkan :

Tabel 2. Gejala penyakit pencernaan

\begin{tabular}{ll}
\hline KODE & \multicolumn{1}{c}{ GEJALA } \\
\hline G1 & Mual \\
G2 & Kembung \\
G3 & Hilang (berkurang) nafsu makan \\
G4 & Muntah \\
G5 & Diare \\
G6 & Tinja bercampur darah \\
G7 & Nyeri perut \\
G8 & Demam \\
G9 & Dada terasa terbakar \\
G10 & Kram perut \\
G11 & Sesekali muntah darah \\
G12 & Sering muntah darah \\
G13 & Perih dari leher sampai perut \\
G14 & Nyeri di leher, pusar dan punggung \\
G15 & Nyeri ulu hati \\
G16 & Berat badan turun drastis \\
G17 & Lidah berwarna putih \\
G18 & Sakit saat buang air \\
\hline
\end{tabular}

Sumber: (Ma'rifati \& Kesuma, 2018)

Tabel 3. Penyakit dan Gejalanya

\begin{tabular}{ll}
\hline \multicolumn{1}{c}{ PENYAKIT } & \multicolumn{1}{c}{ GEJALA } \\
\hline Crohn & G1, G3, G6, G7 \\
Gastritis Akut & G1, G2, G3, G4 \\
Gastritis Kronis & G1, G3, G6, G12 \\
Maag & G1, G3, G7, G13 \\
Tukak Lambung & G1, G3, G7, G14 \\
Gastriporesis & G1, G3, G4, G15 \\
\hline
\end{tabular}




\begin{tabular}{ll}
\hline Gastroenteristis & G1, G3, G4, G16 \\
Usus Buntu & G1, G3, G4, G8, G18 \\
Tifus & G1, G4, G8, G17 \\
Gerd & G1, G4, G9 \\
Iritasi Usu & G1, G5, G10
\end{tabular}

Sumber: (Ma'rifati \& Kesuma, 2018)

Proses analisa klasifikasi Naive Bayes, misalkan seseorang mengalami gejala : Mual (G1), Kembung (G2), Hilang (berkurang) nafsu makan (G3) dan Muntah (G4), maka perhitungannya adalah sebagai berikut :

1. Menentukan Naive Bayes Classifier (nc) Penyakit 1 (Crohn) :

$\mathrm{N}=1$

$\mathrm{P}=1 / 11=0.0909090909091 \mathrm{M}=18$

$\mathrm{G} 1 . \mathrm{nc}=1$

$\mathrm{G} 2 . \mathrm{nc}=0$

$\mathrm{G} 3 . \mathrm{nc}=1$

$\mathrm{G} 4 . \mathrm{nc}=0$

2. Menghitung probabilitas penyakit $1(\mathrm{Crohn})$ :

$$
\begin{aligned}
& \text { 1+18 X } 0.0909090909091
\end{aligned}
$$

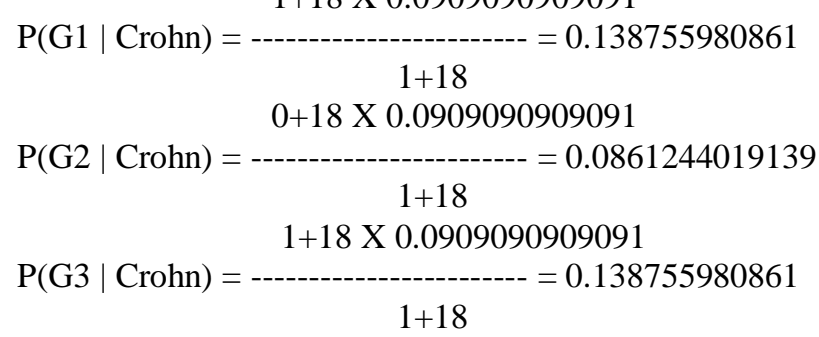

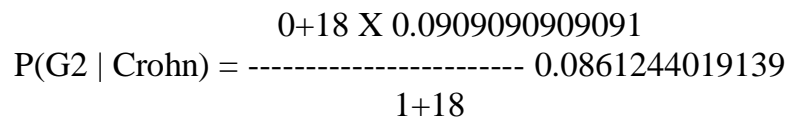

3. Menghitung $\mathrm{P}$ ( $\mathrm{A} \mid \mathrm{B})$ x $\mathrm{P}$ (B ) pada penyakit 1 (Crohn).

$=(\mathrm{P}) \mathrm{X}$ P(G1|Crohn) X P(G2|Crohn) X P(G3|Crohn) X P(G4|Crohn) 0.0909090909091 X 0.138755980861 X 0.0861244019139 X 0.138755980861 X 0.0861244019139

$=1.29826448379 \mathrm{E}-5$

Hitung dengan cara yang sama untuk semua penyakit, hasilnya adalah

Tabel 4. Hasil Perhitungan Peluang Penyakit

\begin{tabular}{ll}
\hline \multicolumn{1}{c}{ Penyakit } & \multicolumn{1}{c}{ Hasil } \\
\hline Gastritis akut & $3.36987787306 \mathrm{E}-5$ \\
Gastroporesis & $2.091648335 \mathrm{E}-5$ \\
Gastroenteritis & $2.091648335 \mathrm{E}-5$ \\
Usus buntu & $2.091648335 \mathrm{E}-5$ \\
Crohn & $1.29826448379 \mathrm{E}-5$ \\
Gastritis kronis & $1.29826448379 \mathrm{E}-5$ \\
Maag & $1.29826448379 \mathrm{E}-5$ \\
Tukak lambung & $1.29826448379 \mathrm{E}-5$ \\
Tifus & $1.29826448379 \mathrm{E}-5$ \\
Gerd & $1.29826448379 \mathrm{E}-5$ \\
Iritasi usus besar & $8.05819334768 \mathrm{E}-6$ \\
\hline
\end{tabular}

Sumber: (Ma'rifati \& Kesuma, 2018)

Berdasarkan hasil perhitungan pada tabel 4 dapat disimpulkan bahwa orang tersebut terkena penyakit Gastritis akut dengan nilai tertinggi yaitu: 3.36987787306E-5.

\subsection{Aplikasi Berbasis Web (Web Apps)}

Dalam ilmu komputer, aplikasi berbasis web (web based application, web apps) adalah aplikasi perangkat lunak client-server dimana klien (user interface) berjalan di web browser. Aplikasinya sendiri disimpan disebuah web server, begitu juga data-data disimpan di database server.

Aplikasi berbasis web memudahkan pengembang karena aplikasi ini dapat berjalan di berbagai platform sistem operasi. Tentu saja karena dijalankan melalui web browser. Oleh karena itu aplikasi dapat dijalankan di sistem berbasis Windows, Linux atau Mac. Aplikasi web biasanya menggunakan kombinasi skrip sisi server (server 
sides script) seperti PHP atau ASP. Dan skrip sisi klient (client side scrip) seperti HTML dan JavaScript. Penggunaan skrip sisi klien berkaitan dengan penyajian informasi sementara skrip sisi server berhubungan dengan pengolahan data termasuk pengambilan dan penyimpanan informasi.

\section{ANALISA DAN PEMBAHASAN}

\subsection{Analisa Masalah}

Menurut dr. Muhammad, Sp.A gangguan pemusatan perhatian atau lebih dikenal sebagai ADHD (Attention Deficit Hyperactivity Disorder) merupakan suatu gejala dimana anak tidak mampu memusatkan perhatian (konsentrasi) pada suatu tugas tertentu, selalu gelisah dan tidak bisa duduk dengan tenang. Penyebabnya adalah adanya kerusakan kecil pada sistem saraf pusat dan otak, sehingga rentang konsentrasi menjadi sangat pendek dan sulit dikendalikan. Anak hiperaktif bergerak kesana dan kemari tidak searah, tidak sesuai dengan situasi yang dihadapi. Merekapun kerap gagal menyelesaikan tugas. Faktor-faktor penyebabnya bisa berupa tempramen bawaan, pengaruh lingkungan, malfungsi otak, epilepsi. Juga kondisi gangguan dikepala, seperti gagar otak, trauma kepala karena persalinan sulit atau kepala pernah terbentur, infeksi, keracunan, gizi buruk, dan alergi makanan. Gangguan ini tidak jelas terlihat, karena anak tidak mengeluh sakit, walau sebetulnya telah terjadi gangguan pada susunan saraf pusat. Anak-anak hiperaktif cenderung tidak menyelesaikan pekerjaannya. Mereka cepat sekali beralih dari satu kegiatan ke kegiatan lainnya. Biasanya perkembangan motorik dan bahasanya juga terhambat. Mereka mudah terangsang, perhatiannya gampang teralihkan, tidak tahan frustasi, dan kurang dapat mengontrol diri. Suasana hatinya juga sangat labil, sebentar gembira dan sebentar marah. Ciri lainnya yaitu tidak dapat mengontrol gerakan. Duduk tidak tenang, bergoyang-goyang atau merosot sehingga terjatuh dari tempat duduk. Sepertinya anak dengan ganggan hiperaktif tidak mengenal lelah. Mulutnya tidak bisa diam, terus berbicara. Daya konsentrasinya rendah seolah-olah tidak bisa mendengarkan perkataan orang tua, dan matanya tidak memperhatikan lawan berbicaranya. Jika anak dengan gangguan hiperaktif didiamkan maka hal tersebut dapat berlanjut hingga dewasa, salah satunya anti sosial.

Pengertian gangguan hiperaktif pada anak tersebut akan dimasukkan kedalam aplikasi sistem pakar berbasis web. Aplikasi sistem pakar ini akan memberikan kemudahan bagi user atau pengguna untuk dapat berkonsultasi layaknya dengan pakar manusia. Salah satu metode pada kecerdasan buatan yang biasa diimplementasikan adalah metode Naive Bayes. Metode Naive Bayes berfungsi sebagai classifier dari beberapa kondisi atribut dari suatu kasus gejala yang diderita oleh anak untuk dapat menentukan probabilitas seorang anak menderita ADHD tipe hiperaktif-impulsif, inatensi atau tipe gabungan. Cara kerja sistem pakar ini adalah user menginputkan gejala-gejala apa saja yang dialami oleh anak. Dari gejala yang diinputkan oleh user, didapat hasil akhir yang menunjukan tipe gangguan ADHD yang diderita oleh anak yaitu tipe hiperaktif-impulsif, inatensi atau tipe gabungan dengan metode Naive Bayes.

\subsection{Analisa Kebutuhan}

Sistem pakar adalah sebuah sistem yang kinerjanya mengadopsi keahlian yang dimiliki seorang pakar dalam bidang tertentu ke dalam sistem atau program komputer yang disajikan dengan tampilan yang dapat digunakan oleh pengguna yang bukan seorang pakar sehingga dengan sistem pakar tersebut pengguna dapat membuat sebuah keputusan atau menentukan kebijakan layaknya seorang pakar. Khususnya sistem pakar mendiagnosa gangguan hiperaktif pada anak. User dapat melakukan konsultasi tentang gangguan hiperaktif pada anak melalui media browser. Berikut ini spesifikasi kebutuhan (system requirement) dari sistem pakar mendiagnosa gangguan hiperaktif pada anak.

A. Analisa Kebutuhan User atau Pengguna

1. User dapat melihat artikel mengenai gangguan hiperaktif pada anak.

2. User dapat melakukan pendaftaran sebelum melakukan konsultasi.

3. User dapat melakukan konsultasi gangguan hiperaktif pada anak dengan mengisi gejala- gejala yang dirasakan kemudian system akan menampilkan hasil diagnosa gangguan hiperaktif yang diderita.

B. Analisa Kebutuhan Admin

1. Admin dapat menambah, menghapus dan mengubah data admin.

2. Admin dapat melihat dan menghapus daftar user atau pengguna yang melakukan pendaftaran dan konsultasi.

3. Admin dapat menambah, mengubah, menghapus dan mengatur apakah artikel ingin ditayangkan atau tidak.

4. Admin dapat menambah, mengubah dan menghapus data gejala penyakit.

5. Admin dapat menambah, mengubah dan menghapus data kategori gejala gangguan hiperaktif.

6. Admin dapat menambah, mengubah dan menghapus jenis penyakit.

7. Admin dapat menambah, mengubah dan menghapus data solusi penyakit.

8. Admin dapat menambah rule pakar gejala penyakit untuk menentukan jenis gejala gangguan hiperaktif pada anak. 


\subsection{Perancangan Objek}

1. Struktur Navigasi

A. Struktur navigasi user

\section{Halaman user sebelum login}

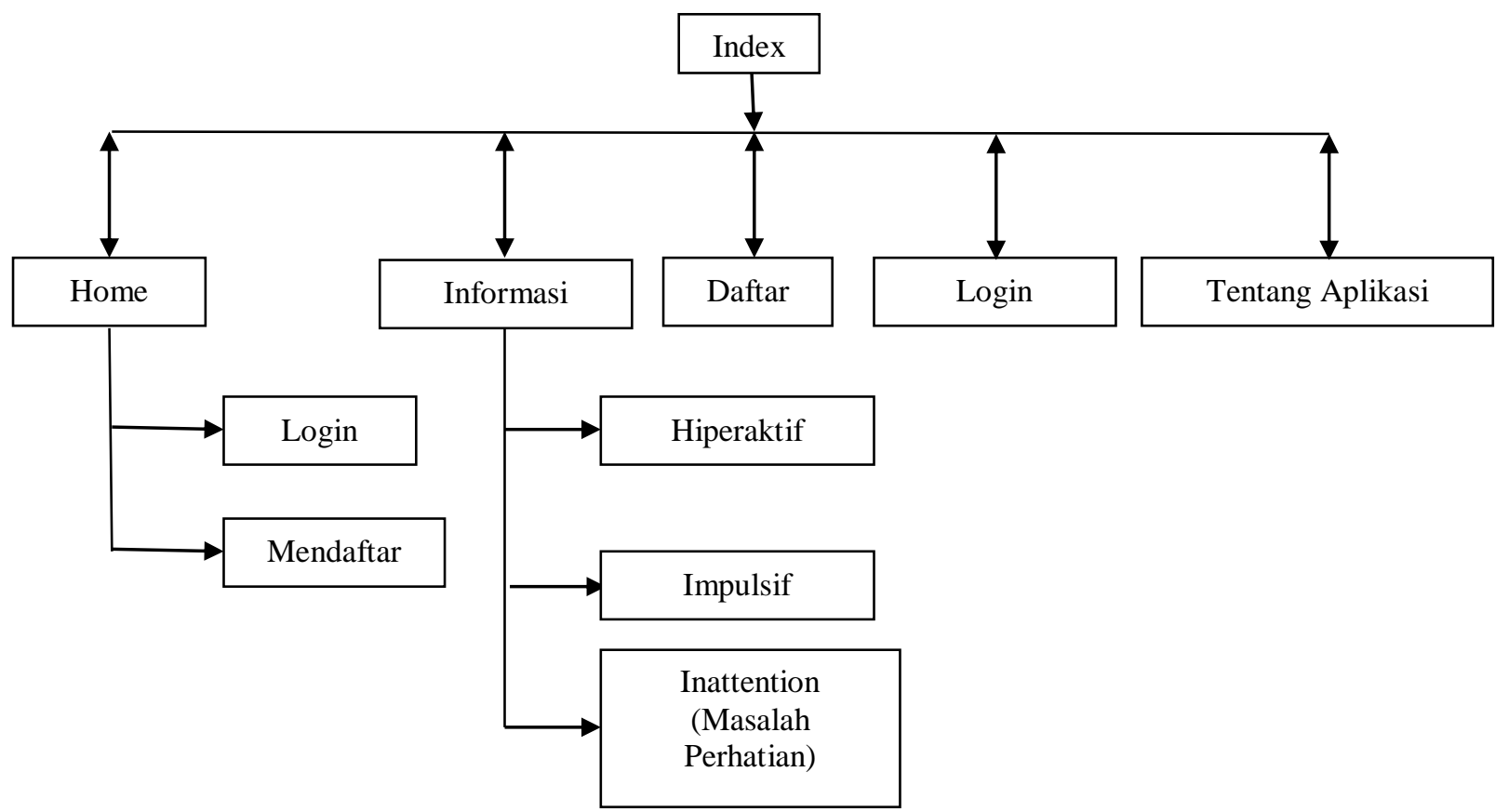

Gambar 1. Struktur Navigasi User Sebelum login

Halaman user sesudah login

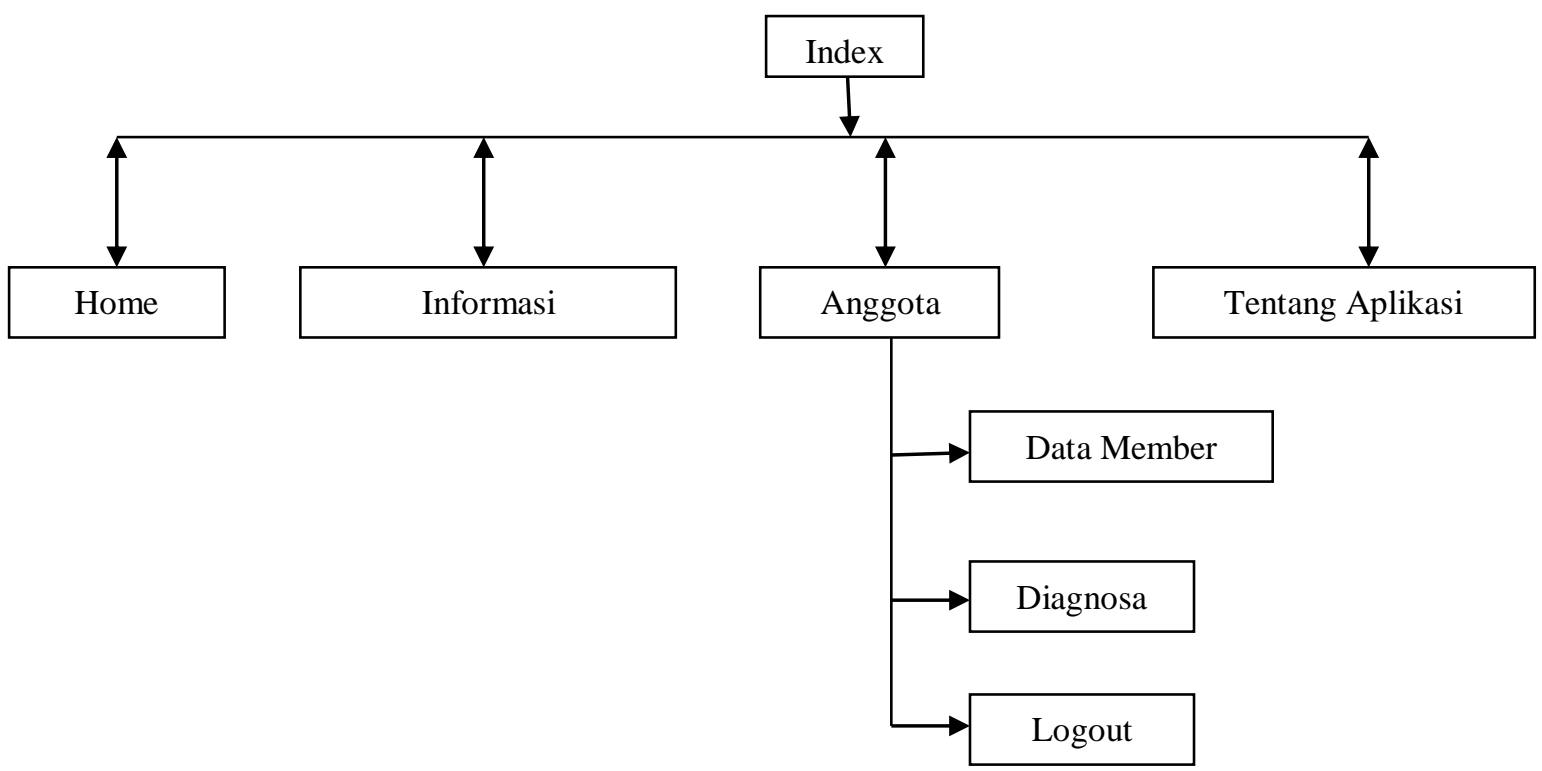

Gambar 2. Struktur Navigasi User Sesudah login 
B. Struktur navigasi admin
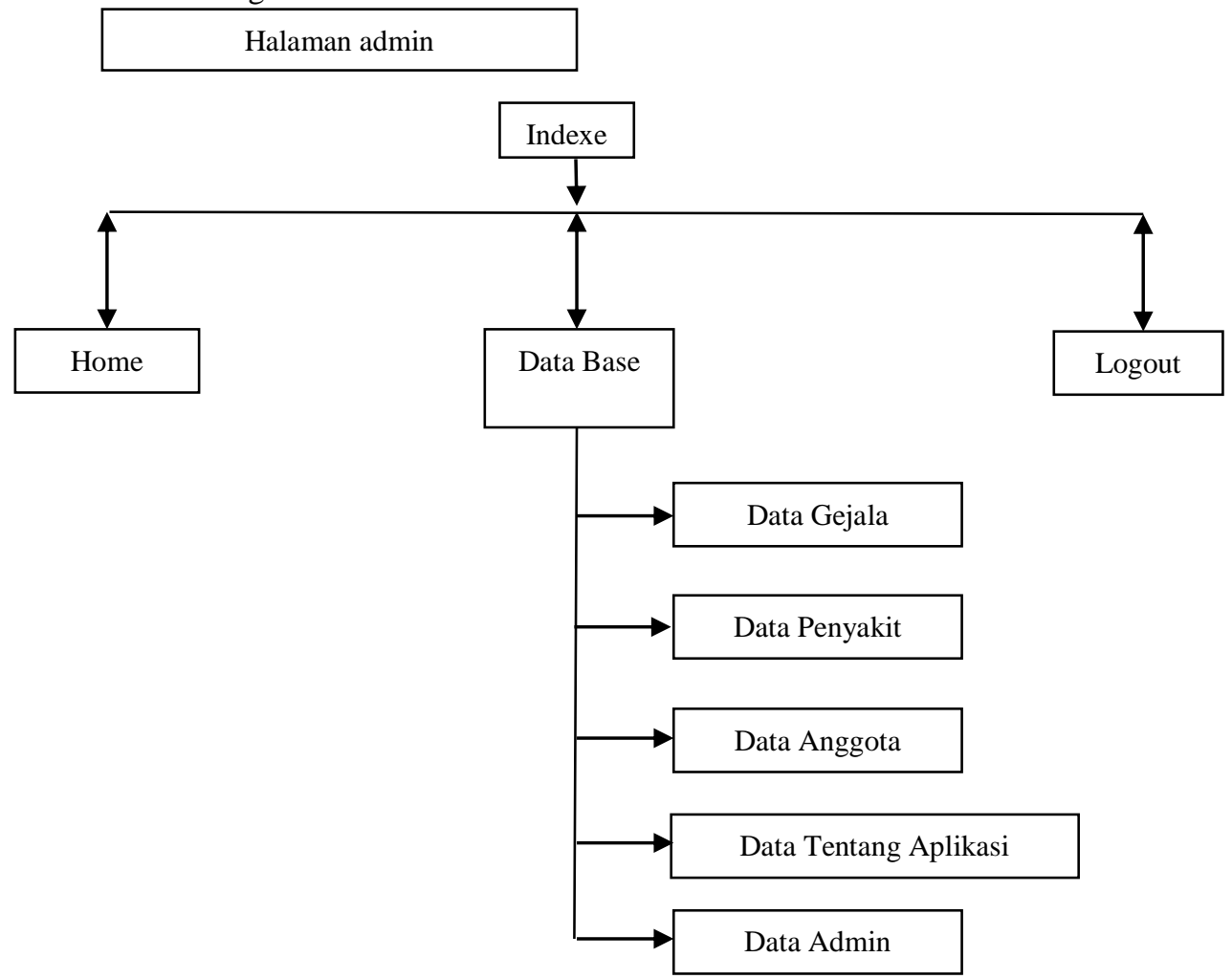

2. Use Case Diagram

Gambar 3. Struktur Navigasi Admin

a.Use case user

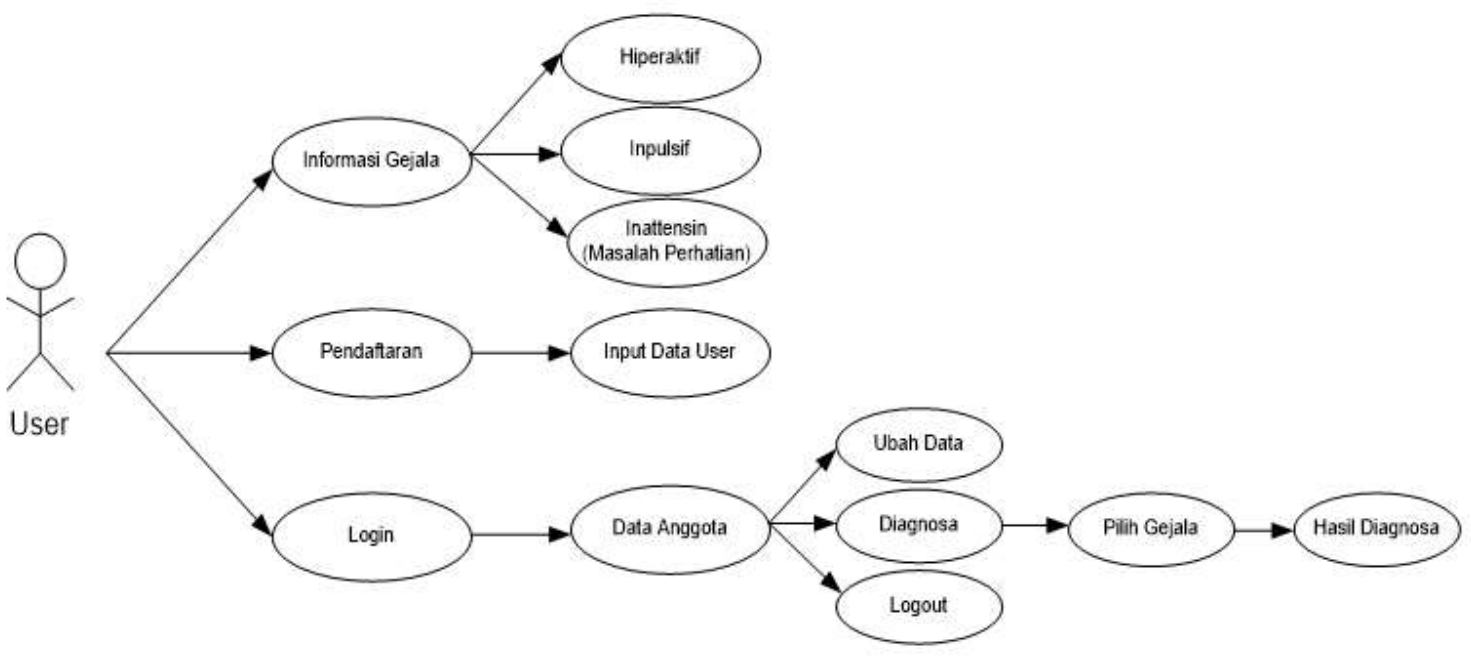

Gambar 4. Use Cse Diagram halaman user atau pengunjung

Tabel 5. Deskripsi Use Case Halaman Informasi Gejala

\begin{tabular}{|l|l|}
\hline Nama Use Case & Melihat Informasi Gejala \\
\hline Aktor & User \\
\hline Deskripsi & User bisa membaca informasi gejala gangguan hiperaktif pada anak \\
\hline Normal Course & $\begin{array}{l}\text { 1. User memilih menu informasi gejala } \\
\text { 2. User dapat membaca informasi penyakit seperti hiperaktif, } \\
\text { impulsive dan inattension (masalah perhatian) } \\
\text { 3. Jika user ingin membaca informasi gejala yang dipilih dapat } \\
\text { mengklik salah satu kategori penyakit. }\end{array}$ \\
\hline Pre-Condition & User masuk ke halaman home \\
\hline Post-Condition & User dapat membaca informasi gejala gangguan hiperaktif pada anak \\
\hline
\end{tabular}


Tabel 6. Deskripsi Use Case Halaman Pendaftaran

\begin{tabular}{|l|l|}
\hline Nama Use Case & Melakukan Pendaftaran \\
\hline Aktor & User \\
\hline Deskripsi & User wajib melakukan pendaftaran sebelum melakukan diagnose \\
\hline Normal Course & $\begin{array}{l}\text { 1. User memilih menu daftar } \\
\text { 2. User mengisikan data user berupa nama lengkap, tanggal lahir, } \\
\text { jenis kelamin, nama orang tua, nomor telfon orang tua. } \\
\text { 3. User klik tombol simpan atau klik tombol batal jika akan } \\
\text { membatalkan pendaftaran }\end{array}$ \\
\hline Pre-Condition & $\begin{array}{l}\text { User wajib melakukan pendaftaran } \\
\text { Post-Condition } \\
\text { hiperaktif mada anak login dan dapat melakukan diagnose gangguan }\end{array}$ \\
\hline
\end{tabular}

Tabel 7. Deskripsi Use Case Halaman Login

\begin{tabular}{|l|l|}
\hline Nama Use Case & Melihat Login \\
\hline Aktor & User \\
\hline Deskripsi & User dapat melakukan login dengan memilih menu login \\
\hline Normal Course & 1. User melakukan login \\
& 2. User mengisikan nomor anggota dan password. \\
& 3. User mengklik tombol login \\
& 4. Sistem akan menampilkan menu anggota. \\
& 5. User dapat mengklik tombol batal jika akan membatalkan login \\
\hline Pre-Condition & User wajib login \\
\hline Post-Condition & User akan masuk pada menu anggota dan dapat melakukan diagnosa \\
& serta dapat melihat riwayat penyakit yang telah dilakukan \\
& sebelumnya. \\
\hline
\end{tabular}

b.Use case Admin
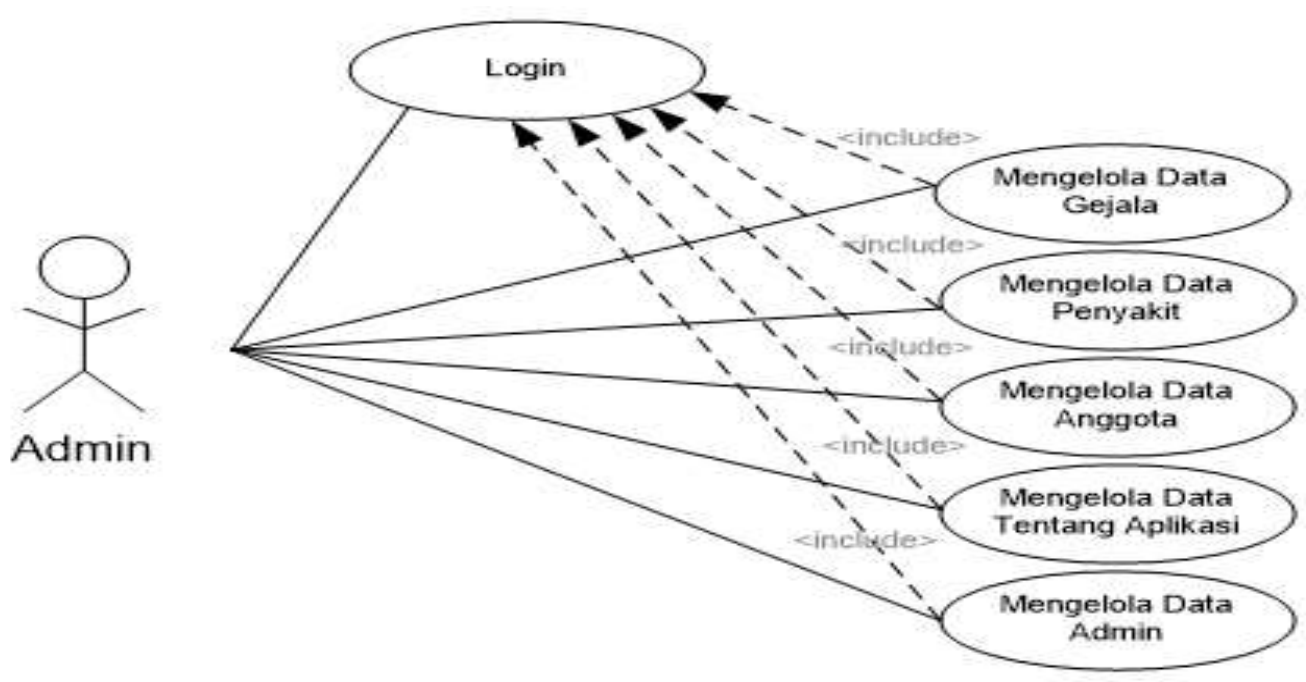

Gambar 5. Use Case Diagram Halaman Admin

Tabel 8. Deskripsi use case Mengelola Data Gejala

\begin{tabular}{|l|l|}
\hline Nama Use Case & Mengelola Gejala \\
\hline Aktor & Admin \\
\hline Deskripsi & Admin dapat menambah, mengubah, menghapus gejala \\
\hline Normal Course & $\begin{array}{l}\text { 1. Admin memilih menu data base } \\
\text { 2. Admin memilih menu data gejala }\end{array}$ \\
& $\begin{array}{l}\text { 3. Admin dapat menambah gejala penyakit dengan mengklik tombol } \\
\text { tambah gejala dan masukkan segi aspek, kode dan gejala kemudian } \\
\text { klik tombol simpan dan klik tombol kembali jika cansel }\end{array}$ \\
& $\begin{array}{l}\text { 4. Admin dapat menghapus data gejala penyakit dengan mengklik } \\
\text { tombol delete atau del }\end{array}$ \\
\hline Pre-Condition & Admin wajib login \\
\hline Post-Condition & Data gejala penyakit tersimpan dan terhapus \\
\hline
\end{tabular}


Tabel 9. Deskripsi use case Mengelola Data Penyakit

\begin{tabular}{|l|l|}
\hline Nama Use Case & Mengelola Data Penyakit \\
\hline Aktor & Admin \\
\hline Deskripsi & Admin dapat menambah, mengubah, menghapus data penyakit \\
\hline Normal Course & $\begin{array}{l}\text { 1. Admin memilih menu data base } \\
\text { 2. Admin memilih menu data penyakit }\end{array}$ \\
& $\begin{array}{l}\text { 3. Admin dapat menambah data penyakit dengan mengklik tombol } \\
\text { tambah penyakit dan masukkan nama penyakit, ringkasan dan } \\
\text { deskripsi kemudian klik tombol simpan atau klik tombol kembali } \\
\text { jika cancel }\end{array}$ \\
& $\begin{array}{l}\text { 4. Admin dapat mengubah data penyakit seperti nama penyakit, } \\
\text { ringkasan dan deskripsi kemudian klik tombol edit atau klik tombol } \\
\text { kembali jika cancel }\end{array}$ \\
& $\begin{array}{l}\text { 5. Admin dapat menghapus data kategori penyakit dengan mengklik } \\
\text { tombol delete atau del }\end{array}$ \\
\hline Pre-Condition & Admin wajib login \\
\hline Post-Condition & Data kategori penyakit tersimpan dan terhapus \\
\hline
\end{tabular}

Tabel 10.Deskripsi use case Mengelola Data Anggota

\begin{tabular}{|l|l|}
\hline Nama Use Case & Mengelola Data Anggota \\
\hline Aktor & Admin \\
\hline Deskripsi & Admin dapat melihat riwayat, mengubah, dan menghapus data anggota \\
\hline Normal Course & $\begin{array}{l}\text { 1. Admin memilih menu data base } \\
\text { 2. Admin memilih menu data anggota }\end{array}$ \\
& $\begin{array}{l}\text { 3. Admin dapat melihat riwayat anggota dengan mengklik tombol } \\
\text { riwayat }\end{array}$ \\
& $\begin{array}{l}\text { 4. Admin dapat mengubah data anggota dengan mengklik tombol edit } \\
\text { 5. Admin dapat menghapus data anggota dengan mengklik tombol } \\
\text { delete atau del }\end{array}$ \\
\hline Pre-Condition & Admin wajib login \\
\hline Post-Condition & Data anggota tersimpan dan terhapus \\
\hline
\end{tabular}

Tabel 11. Deskripsi use case Mengelola Data Tentang Aplikasi

\begin{tabular}{|l|l|}
\hline Nama Use Case & Mengelola Data Tentang Aplikasi \\
\hline Aktor & Admin \\
\hline Deskripsi & Admin dapat menambah, mengubah, menghapus data tentang aplikasi \\
\hline Normal Course & 1. Admin memilih menu data base \\
& $\begin{array}{l}\text { 2. Admin memilih menu data tentang aplikasi } \\
\text { 3. Admin dapat menambah data tentang aplikasi dengan mengklik } \\
\text { tombol tambah tentang }\end{array}$ \\
& $\begin{array}{l}\text { 4. Admin dapat mengubah data tentang aplikasi dengan mengklik } \\
\text { tombol edit }\end{array}$ \\
& $\begin{array}{l}\text { 5. Admin dapat menghapus data tentang aplikasi dengan mengklik } \\
\text { tombol delete atau del }\end{array}$ \\
\hline Pre-Condition & Admin wajib login \\
\hline Post-Condition & Data tentang aplikasi tersimpan dan terhapus \\
\hline
\end{tabular}

Tabel 12. Deskripsi Use Case Mengelola Data Admin

\begin{tabular}{|l|l|}
\hline Nama Use Case & Mengelola Data Admin \\
\hline Aktor & Admin \\
\hline Deskripsi & Admin dapat menambah, mengubah dan menghapus data admin \\
\hline Normal Course & $\begin{array}{l}\text { 1. Admin memilih menu data base } \\
\text { 2. Admin memilih menu data admin }\end{array}$ \\
& $\begin{array}{l}\text { 3. Admin dapat melakukan penambahan data admin dengan mengklik } \\
\text { tombol tambah dan masukkan data seperti (nama admin, nama } \\
\text { admin, login dan password) kemudian klik tombol simpan jika ingin } \\
\text { di save atau klik tombol kembali jika cancel }\end{array}$ \\
& $\begin{array}{l}\text { 4. Admin dapat mengubah data admin seperti nama admin, login, dan } \\
\text { password dengan mengkilk tombol edit dan klik kembali jika cancel }\end{array}$ \\
& 5. Admin dapat menghapus data admin dengan mengklik tombol delete \\
\hline
\end{tabular}




\begin{tabular}{|l|l|}
\hline Nama Use Case & Mengelola Data Admin \\
\hline & atau del \\
\hline Pre-Condition & Admin wajib login \\
\hline Post-Condition & Data admin tersimpan dan terhapus \\
\hline
\end{tabular}

3. Activity Diagram

a. Activity Diagram Login Anggota

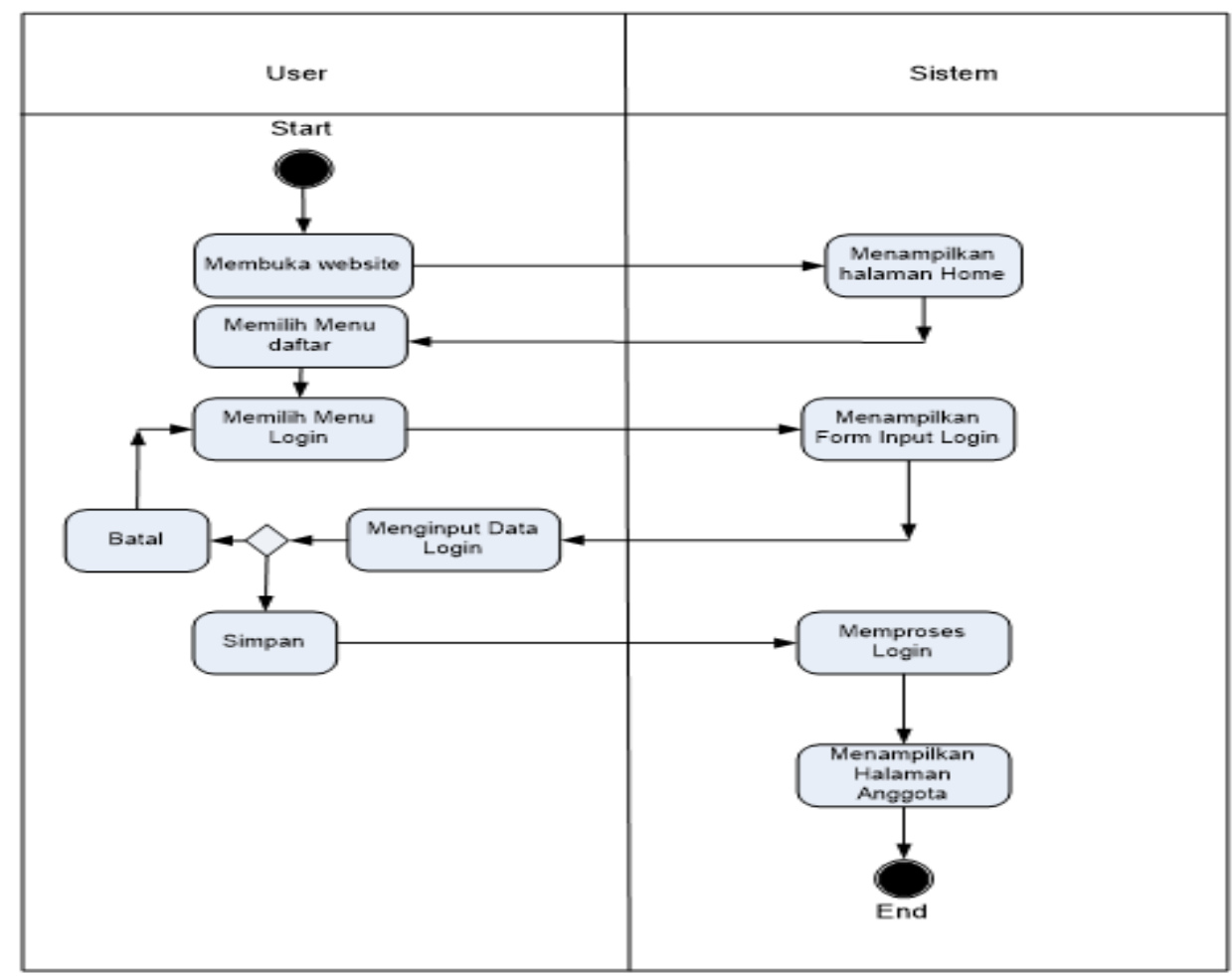

Gambar 6. Activity Diagram Login Anggota

b. Activity Diagram Login Pendaftaran

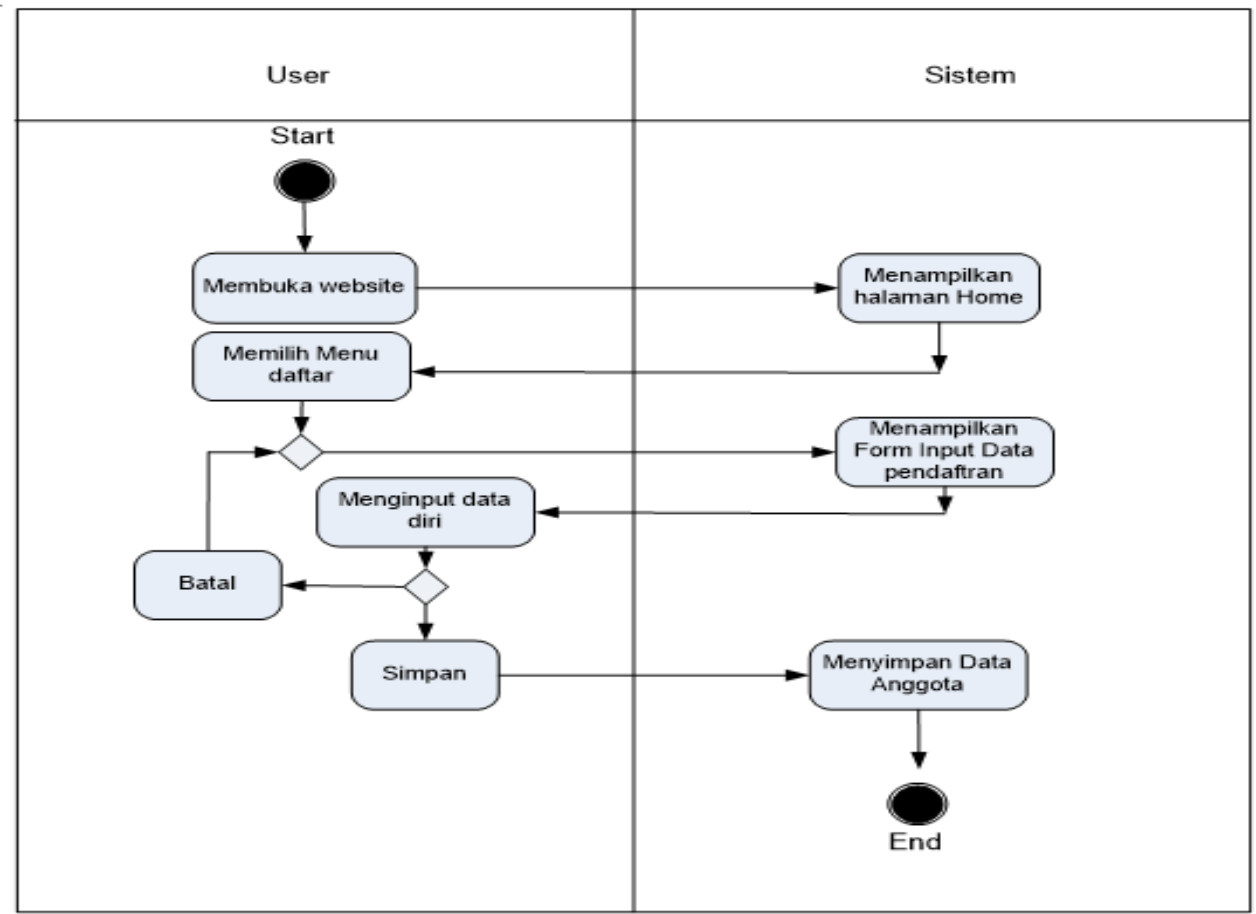

Gambar 7. Activity Diagram Login Pendaftaran

Yunia Ervinaeni | http://ejurnal.stmik-budidarma.ac.id/index.php/mib | Page 99 


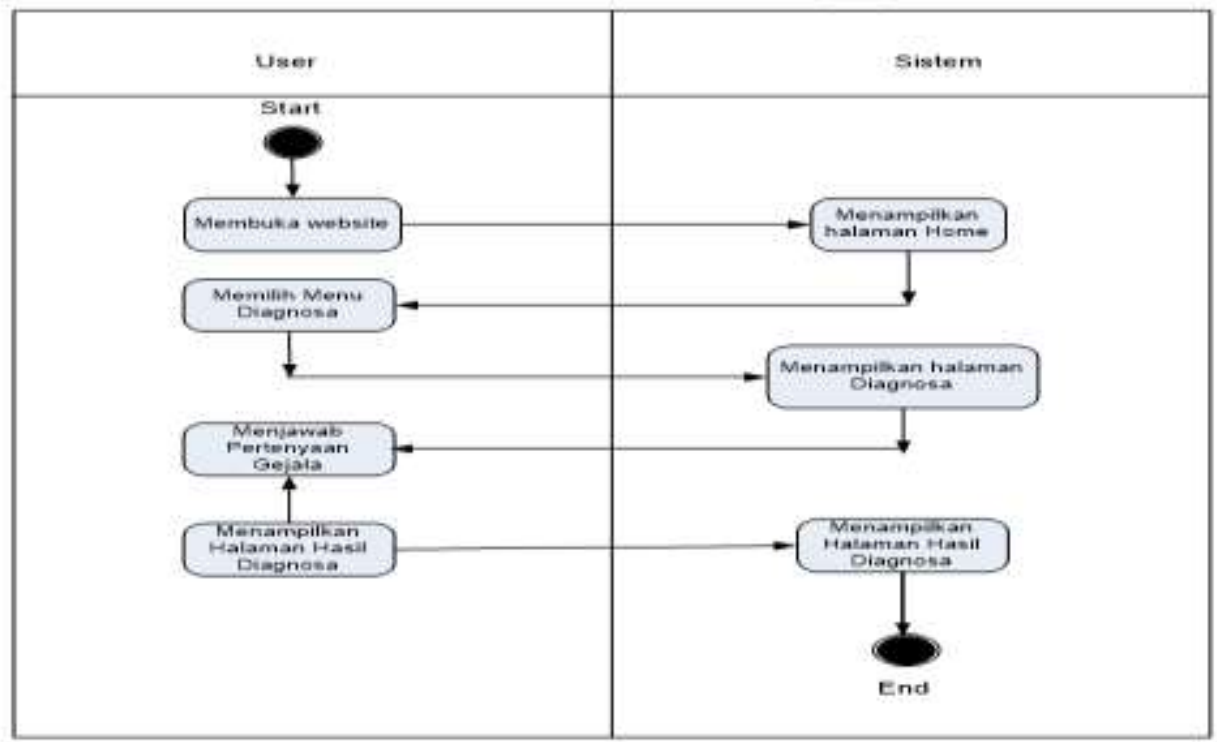

Gambar 8. Activity Diagram Proses

\section{IMPLEMENTASI}

\subsection{Implementasi Hasil}

Berikut ini beberapa implementasi hasil yang terdapat dalam aplikasi sistem pakar diagnosa gangguan hiperaktif pada anak.

1. Implementasi Hasil Halaman User

a. Implementasi hasil menu beranda

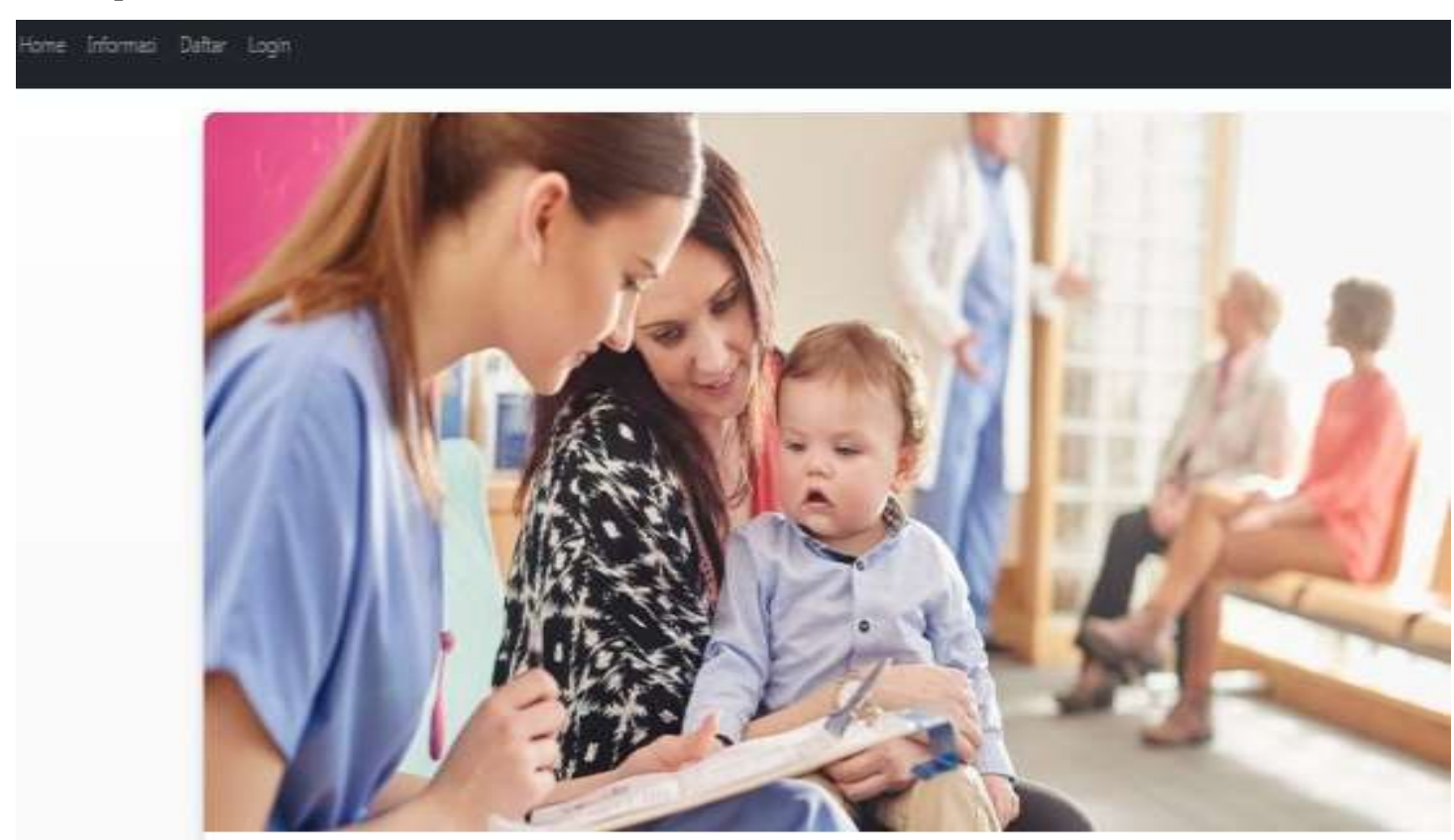

Sictem Pakar Autisme adaleh aplilas sistem palar untul mendiagnosa gejala autisme pada anak. Dengan menggunakan apkas in Anda dacat mengetahu aoakah anak Anda menderta autome

Untuk memulai diagnosa silahkan login terlebih dahulu. Jika anda belum memiliki akun, silahkan mendaftar.

Gambar 9. Menu beranda 
b. Tampilan hasil menu Informasi hasil

\section{HASIL DIAGNOSA}

Hacl analict terhadap gejal y yng anda olth adalan yebaga berhur

Hiperaktif (50\%)

Inattension_(Masalah Perhatian)_(25\%)

Impulsif (25\%)

\section{vimoan Eurs}

Gambar 10. Tampilan menu Informasi Hasil

\subsection{Hasil Pengujian}

Hasil pengujian yang didapatkan pada aplikasi sistem pakar berbasis web sebagai berikut :

Tabel 13. Jenis Gejala Gangguan Hiperaktif

\begin{tabular}{lll}
\hline No & \multicolumn{1}{c}{ Penyakit } & \multicolumn{1}{c}{ Gejala } \\
\hline 1 & Hiperaktif & G09 G10 G11 G12 G13 G14 \\
2 & Inattention & G01 G02 G03 G04 G05 G06 G07 G08 \\
3 & Impulsive & G15 G16 G17 \\
\hline
\end{tabular}

Peluang Penyakit $[\mathrm{P}]=1 /$ jumlah penyakit $=1 / 3=0,333333$

Misalkan Gejala yang terpilih adalah:

1. Sering mengalami kesulitan menjaga perhatian/konsentrasi dalam menerima tugas atau aktifitas bermain (G02).

2. Sering kesulitan mengatur tugas dan kegiatan (G04).

3. Sering merasa gelisah tampak pada tangan, kaki dan menggeliat dalam tempat duduk (G09).

4. Sering sulit menunggu giliran atau antrian (G16).

Jumlah gejala yang dipilih $=4$

1. Perhitungan Peluang Gejala Terhadap Penyakit

A. PerhitunganGejalapada P1 (Hiperaktif)

PeluangP1 $\mid \mathrm{G} 02$, dimana G02bukangejala $\mathrm{P} 1=\frac{0}{4}=0$

Peluang P1|G04, dimana G04 bukangejala $\mathrm{P} 1=\frac{0}{4}=0$

PeluangP1|G09, dimanaG09gejala $\mathrm{P} 1=\frac{1}{4}=0,25$

PeluangP1 $\mid$ G16, dimanaG16 bukangejala P1 $=\frac{0}{4}=0$

B. PerhitunganGejalapada P2 (Inattention)

Peluang P2 $\mid \mathrm{G} 02$, dimana G02 gejala $\mathrm{P} 2=\frac{1}{4}=0,25$

Peluang P2|G04, dimana G04 gejala P2 $=\frac{1}{4}=0,25$

Peluang P2 $\mid \mathrm{G} 09$, dimana G09 bukangejala $\mathrm{P} 2=\frac{0}{4}=0$

Peluang P2 $\mid \mathrm{G} 16$, dimana G16 bukangejala $\mathrm{P} 2=\frac{0}{4}=0$

C. PerhitunganGejalapada P3 (Impulsive)

Peluang P3 $\mid \mathrm{G} 02$, dimana G02 bukangejala $\mathrm{P} 3=\frac{0}{4}=0$

Peluang P3 $\mid$ G04, dimana G04 bukangejala $\mathrm{P} 2=\frac{0}{4}=0$

Peluang P3 $\mid$ G09, dimana G09 bukangejala P3 $=\frac{0}{4}=0$ 
JURNAL MEDIA INFORMATIKA BUDIDARMA, Vol 3, No 2, April 2019

ISSN 2614-5278 (media cetak)

ISSN 2548-8368 (media online)

Hal 90-104 | DOI: 10.30865/mib.v3i2.1158

Peluang P3|G16, dimana G16 gejala P3 $=\frac{1}{4}=0,25$

2. Perhitungan Naïve Bayes Gejala Terhadap Penyakit

A. Naive Bayes P1 (Hiperaktif)

$$
\begin{aligned}
\mathrm{P} 1 \mid \mathrm{G} 02= & \frac{[\mathrm{P} 1 \mid \mathrm{G} 02] \mathrm{X}[\mathrm{P}]}{\lceil\mathrm{P} 1 \mid \mathrm{G} 02] \mathrm{X}[\mathrm{P}]+[\mathrm{P} 2 \mid \mathrm{G} 02] \mathrm{X}[\mathrm{P}]+[\mathrm{P} 3 \mid \mathrm{G} 02] \mathrm{X}\lceil\mathrm{P} \mid} \\
& =\frac{0 \times 0,3333}{0 \mathrm{X} 0,3333+0,25 \times 0,3333+0 \times 0,3333} \\
& =\frac{0}{0,08333325}=0
\end{aligned}
$$

$$
\begin{aligned}
\mathrm{P} 1 \mid \mathrm{G} 04 & =\frac{\{\mathrm{P} 1 \mid \mathrm{G} 04] \mathrm{X}[\mathrm{P}]}{\lceil\mathrm{P} 1 \mid \mathrm{G} 04] \mathrm{X}[\mathrm{P} 1+[\mathrm{P} 2 \mid \mathrm{G} 04] \mathrm{X}[\mathrm{P}\rceil+[\mathrm{P} 3 \mid \mathrm{G} 04] \mathrm{X}[\mathrm{P} \mid} \\
& =\frac{0 \times 0,3333}{0 \times 0,3333+0,25 \times 0,3333+0 \times 0,3333} \\
& =\frac{0}{0,08333325}=0
\end{aligned}
$$

$$
\begin{aligned}
\mathrm{P} 1 \mid \mathrm{G} 09= & \frac{\{\mathrm{P} 1 \mid \mathrm{G} 09] \mathrm{X}[\mathrm{P}]}{\lceil\mathrm{P} 1 \mid \mathrm{G} 09] \mathrm{X}\lceil\mathrm{P} \mid+[\mathrm{P} 2 \mid \mathrm{G} 09] \mathrm{X}[\mathrm{P}\rceil+[\mathrm{P} 3 \mid \mathrm{G} 09] \mathrm{X}\lceil\mathrm{P}\rceil} \\
& =\frac{0,25 \times 0,3333}{0,25 \times 0,3333+0 \times 0,3333+0 \times 0,3333} \\
& =\frac{0,08333325}{0,08333325}=1
\end{aligned}
$$$$
\mathrm{P} 1 \mid \mathrm{G} 16=\frac{\{\mathrm{P} 1 \mid \mathrm{G} 16] \mathrm{X}[\mathrm{P}]}{[\mathrm{P} 1 \mid \mathrm{G} 16] \mathrm{X}\lceil\mathrm{P} \mid+[\mathrm{P} 2 \mid \mathrm{G} 16] \mathrm{X}\lceil\mathrm{P}\rceil+[\mathrm{P} 3 \mid \mathrm{G} 16] \mathrm{X}\lceil\mathrm{P}]}
$$$$
=\overline{0 \times 0,3333+0 \times 0,3333+0,25 \times 0,3333}
$$$$
=\frac{0}{0,08333325}=0
$$

Jumlah Naïve Bayes P1 $=0+0+1+0=1$

B. Naive Bayes P2 (Inattention)

$$
\begin{aligned}
& \mathrm{P} 2 \mid \mathrm{G} 02=\frac{\{\mathrm{P} 2 \mid \mathrm{G} 02] \mathrm{X}[\mathrm{P}]}{\lceil\mathrm{P} 1 \mid \mathrm{G} 02\rceil \mathrm{X}\lceil\mathrm{P} \mid+[\mathrm{P} 2 \mid \mathrm{G} 02\rceil \mathrm{X}\lceil\mathrm{P}\rceil+[\mathrm{P} 3 \mid \mathrm{G} 02\rceil \mathrm{X}\lceil\mathrm{P}\rceil} \\
& =\frac{0,25 \times 0,3333}{0 \times 0,3333+0,25 \times 0,3333+0 \times 0,3333} \\
& =\frac{0,08333325}{0,08333325}=1 \\
& \mathrm{P} 2 \mid \mathrm{G} 04=\frac{\{\mathrm{P} 2 \mid \mathrm{G} 04] \mathrm{X}[\mathrm{P}]}{\lceil\mathrm{P} 1 \mid \mathrm{G} 04] \mathrm{X}\lceil\mathrm{P} \mid+[\mathrm{P} 2 \mid \mathrm{G} 04] \mathrm{X}\lceil\mathrm{P}\rceil+[\mathrm{P} 3 \mid \mathrm{G} 04] \mathrm{X}\lceil\mathrm{P}\rceil} \\
& =\frac{0,25 \times 0,3333}{0 \times 0,3333+0,25 \times 0,3333+0 \times 0,3333} \\
& =\frac{0,08333325}{0,08333325}=1 \\
& \mathrm{P} 2 \mid \mathrm{G} 09=\frac{\{\mathrm{P} 2 \mid \mathrm{G} 09] \mathrm{X}[\mathrm{P}]}{[\mathrm{P} 1 \mid \mathrm{G} 09] \mathrm{X}[\mathrm{P} \mid+[\mathrm{P} 2 \mid \mathrm{G} 09] \mathrm{X}[\mathrm{P} \mid+[\mathrm{P} 3 \mid \mathrm{G} 09] \mathrm{X}[\mathrm{P}]} \\
& =\frac{0,0 \times 0,3333}{0,25 \times 0,3333+0 \times 0,3333+0 \times 0,3333} \\
& =\frac{0}{0,08333325}=0
\end{aligned}
$$




$$
\begin{aligned}
& \mathrm{P} 2 \mid \mathrm{G} 16=\frac{\{\mathrm{P} 2 \mid \mathrm{G} 16] \mathrm{X}[\mathrm{P}]}{[\mathrm{P} 1 \mid \mathrm{G} 16] \mathrm{X}[\mathrm{P} \mid+[\mathrm{P} 2 \mid \mathrm{G} 16] \mathrm{X}\lceil\mathrm{P} \mid+[\mathrm{P} 3 \mid \mathrm{G} 16] \mathrm{X}\lceil\mathrm{P}\rceil} \\
& =\frac{0 \times 0,3333}{0 \times 0,3333+0 \times 0,3333+0,25 \times 0,3333} \\
& =\frac{0}{0,08333325}=0 \\
& \text { Jumlah Naïve Bayes P2 }=1+1+0+0=2 \\
& \mathrm{P} 3 \mid \mathrm{G} 02=\frac{\{\mathrm{P} 3 \mid \mathrm{G} 02] \mathrm{X}[\mathrm{P}]}{\lceil\mathrm{P} 1 \mid \mathrm{G} 02\rceil \mathrm{X}\lceil\mathrm{P}\rceil+\lceil\mathrm{P} 2 \mid \mathrm{G} 02\rceil \mathrm{X}\lceil\mathrm{P} \mid+[\mathrm{P} 3 \mid \mathrm{G} 02\rceil \mathrm{X}\lceil\mathrm{P}\rceil} \\
& =\frac{0 \times 0,3333}{0 \times 0,3333+0,25 \times 0,3333+0 \mathrm{X}_{0} 3333} \\
& =\frac{0}{0,08333325}=0 \\
& \begin{aligned}
\mathrm{P} 3 \mid \mathrm{G} 04= & \frac{\{\mathrm{P} 3 \mid \mathrm{G} 04] \mathrm{X}[\mathrm{P}]}{\lceil\mathrm{P} 1 \mid \mathrm{G} 04] \mathrm{X}[\mathrm{P} \mid+[\mathrm{P} 2 \mid \mathrm{G} 04] \mathrm{X}[\mathrm{P}\rceil+[\mathrm{P} 3 \mid \mathrm{G} 04] \mathrm{X}[\mathrm{P}]} \\
& =\frac{0 \mathrm{X} 0,3333}{0 \times 0,3333+0,25 \times 0,3333+0 \times 0,3333} \\
& =\frac{0}{0,08333325}=0
\end{aligned} \\
& \mathrm{P} 2 \mid \mathrm{G} 09=\frac{\{\mathrm{P} 2 \mid \mathrm{G} 09] \mathrm{X}[\mathrm{P}]}{[\mathrm{P} 1 \mid \mathrm{G} 09] \mathrm{X}[\mathrm{P} \mid+[\mathrm{P} 2 \mid \mathrm{G} 09] \mathrm{X}[\mathrm{P} \mid+[\mathrm{P} 3 \mid \mathrm{G} 09] \mathrm{X}[\mathrm{P}]} \\
& =\frac{0,0 \times 0,3333}{0,25 \times 0,3333+0 \times 0,3333+0 \times 0,3333} \\
& =\frac{0}{0,08333325}=0
\end{aligned}
$$

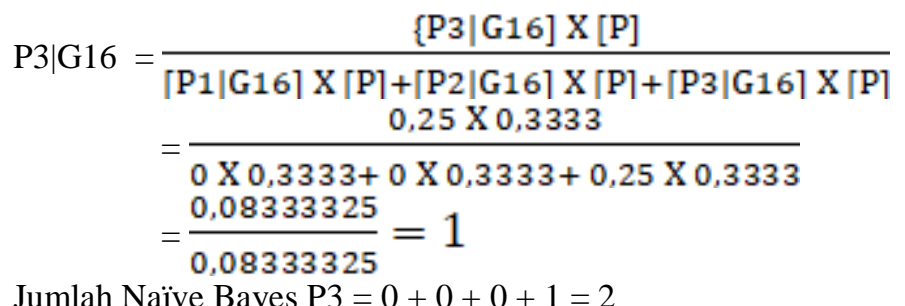

Tabel 14. Hasil Nilai Total

\begin{tabular}{lcc}
\hline \multicolumn{1}{c}{ Penyakit } & Naïve Bayes & Persen \\
\hline Hiperaktif & 1 & $25 \%$ \\
Inaattention & 2 & $50 \%$ \\
Impulsif & 1 & $25 \%$ \\
Jumlah & 4 & $100 \%$ \\
\hline
\end{tabular}

Berdasarkan hasil perhitungan pada tabel 14 dapat disimpulkan bahwa anak tersebut terkena gejala gangguan Inattention dengan nilai tertinggi yaitu: $50 \%$

\section{KESIMPULAN}

Dari keseluruhan hasil penulisan jurnal tentang pembuatan aplikasi diagnosa gangguan hiperaktif pada anak menggunakan sistem pakar berbasis web, dapat dikatakan bahwa user interface mengkomunikasikan fitur-fitur sistem yang tersedia agar user mengerti dan dapat menggunakan sistem tersebut, maka dapat disimpulkan bahwa:

1. Sistem pakar diagnosa gangguan hiperaktif menggunakan metode naive bayes dapat memberikan hasil berupa prosentase angka.

2. Sistem pakar dengan menentukan hiperaktif pada anak dapat dibuat sebuah aplikasi berbasis web dan menggunakan metode naive bayes dalam mendiagnosa seorang anak yang menderita gangguan hiperaktif. 
3. Masyarakat menjadi lebih mengerti mengenai variabel gejala-gejala gangguan hiperaktif pada anak.

4. Sebuah web dapat dijadikan bahan untuk membuat aplikasi dalam mendiagnosa gangguan hiperaktif pada anak.

\section{REFERENCES}

[1] Argario, Healtho Brilian, Nurul Hidayat dan Ratih Kartika Dewi. 2018. Implementasi Metode Naïve Bayes Untuk Diagnosis Penyakit Kambing (Studi Kasus : UPTD. Pembibitan Ternak dan Hijauan Makanan Ternak Kec. Singosari Malang). Vol. 2, No. 8

[2] Diah, R. A., \& Fadlillah, U. (2015). Rancang Bangun Website dan E-Learning di TPQ Al-Fadhillah, I(1), 40-43.

[3] Fanny, Rahmi Ras, Nelly Astuti Hasibuan, Efori Buulolo. 2017. Perancangan Sistem Pakar Diagnosa Penyakit Asidosis Tubulus Renalis Menggunakan Metode Certainty Factor dengan Penelusuran Forward Chaining. Vol1, No. 1

[4] Habibie, F. H., Purnama, B. E., \& Triyono, R. A. (2014). SECARA ONLINE BERBASIS WEB PADA BURSA KERJA KHUSUS, $77-83$.

[5] Kuryati, S. J. (2015). RANCANGAN APLIKASI PENGAJUAN KARTU KUNING SECARA ONLINE ( STUDI KASUS : DINAS TENAGA KERJA DAN TRANSMIGRASI KABUPATEN MUSI RAWAS ), 33-37.

[6] Ma'rifati, Imam Soleh dan Chandra Kesuma.2018. PENGEMBANGAN SISTEM PAKAR MENDETEKSI PENYAKIT PENCERNAAN MENGGUNAKAN METODE NAIVE BAYES BERBASIS WEB

[7] Muslim, M. A., \& Pramesti, A. A. (2014). Penyajian Data Pelanggan pada Lima Area PT . Telekomunikasi Indonesia , Tbk ., 1(2), 193-200.

[8] Novriana, Dita Eka. dkk. 2013. Prevalensi Gangguan Pemusatan Perhatian dan Hiperaktivitas pada Siswa dan Siswi Sekolah Dasar Negeri Kecamatan Padang Timur Kota Padang Tahun 2013.

[9] Nugraha, Deny Wiria,. A.Y. Erwin Dodu, Novilia Chandra.2017. KLASIFIKASI PENYAKIT STROKE MENGGUNAKAN METODE NAIVE BAYES CLASSIFIER (STUDI KASUS PADA RUMAH SAKIT UMUM DAERAH UNDATA PALU). Vol.3, No.2

[10] Kusrini, 2008. APLIKASI SISTEM PAKAR Menentukan Faktor Kepastian Pengguna dengan Metode Kualifikasi Pertanyaan. Yogyakarta: CV. ANDI OFFSET (Penerbit Andi).

[11] Rosa, A.S dan M. Shalahuddin. 2013. Rekayasa Perangkat Lunak Terstruktur dan Berorientasi Objek. Bandung: Informatika.

[12] Sabransyah, M, Yuki Novia Nasution, dan Fidia Deny Tisna Amijaya.2017. Aplikasi Metode Naive Bayes dalam Prediksi Risiko Penyakit Jantung Naive Bayes Method for a Heart Risk Disease Prediction Application. vol.8, No.2.

[13] Setianingsih, Amila Wahyuni Ardani, Firiana Noor Khayati. 2018. DAMPAK PENGGUNAAN GADGET PADA ANAK USIA PRASEKOLAH DAPAT MENINGKATAN RESIKO GANGGUAN PEMUSATAN PERHATIAN DAN HIPERAKTIVITAS. vol.2

[14] Siahaan, D. (2016). Aplikasi Classification and Regresion Tree (CART) dan Regresi Logistik Ordinal dalam Bidang Ilmu Pendidikan dengan Studi Kasus Predikat Kelulusan Mahasiswa S1 FMIPA Universitas Mulawarman. Jurnal Exponensial, 7(1), 95-104

[15] Saifudin, \& Maharani, K. M. D. (2017). Sistem Informasi Pemesanan Tiket Shuttle Berbasis Web Pada PO . Sumber Alam Purwokerto, 7(3), 8-14.

[16] Sitorus, Lamhot. 2015. Algoritma dan Pemrograman. Yogyakarta: Andi.

[17] Wijaya, Yeny Duriana.2015. POSITIVE PARENTING PROGRAM (TRIPLE P) SEBAGAI USAHA UNTUK MENURUNKAN PENGASUHAN DISFUNGSIONAL PADA ORANGTUA YANG MEMPUNYAI ANAK BERKEBUTUHAN KHUSUS (DENGAN DIAGNOSA AUTIS DAN ADHD).

[18] Wijianto, R., \& Anggoro, A. (2018). SISTEM INFORMASI PENDAFTARAN SELEKSI KERJA BERBASIS WEB PADA BKK ( BURSA KERJA KHUSUS ) TUNAS INSAN KARYA SMK NEGERI 2, 6(1), 76-84. 